\title{
Possible moral ecologies, the function of everyday curation, and the experience of regions
}

\author{
Kirsten Valentine Cadieux ${ }^{1}$ \\ Hamline University, USA
}

\begin{abstract}
Investigating the political ecologies of everyday engagements with environments_including material as well as policy and ideological interactions - requires consideration of the moral economy at play, as well as the political economy and social ecology. A.V. Chayanov (1966/1925), E.P. Thompson (1971, 1991), and Jim Scott (1976) have provided useful ways to think about moral economy. They framed moral economy as a way of enacting understandings of just commons, subsistence entitlements, and desirable economic relations based on social struggle. This framing can be particularly useful in combination with political ecology approaches to investigate 'moral ecologies.' These are society-environment assemblages that are often more aspirational than enacted, but toward which considerable effort is expended, and whose moral and ecological dynamics are functionally linked, perhaps as best illustrated in recent attention to agroecology as a powerful mechanism for ensuring rights to food (De Schutter 2011a, 2011b, 2012). Given political ecology's focus on power relations, moral ecologies that do not exercise considerable power are often overlooked by political ecologists. However, even if particular understandings may not be highly efficacious in exercising power, they may have considerable influence on relational conceptualizations. This mismatch between habitual inattention to moral ecologies and their potential importance contributes to tensions within contemporary society-environment scholarship between structuralist and poststructuralist modes of engagement. Given the value of both modes, particularly for understanding what Peet and Watts (1993) describe as liberation ecologies (and the regional discourse formations that shape them), I argue that political ecology provides useful frameworks for documenting and analyzing the socio-ecological experience of regions-in terms not only of the functions of society and environment, but also of the performance and curation of knowledge about those functions.
\end{abstract}

Keywords: moral economy, food systems, curation, critical regional studies, land use planning, participatory action research, environmental justice, integrated natural resource management science

\section{Résumé}

Enquêter sur les écologies politiques des interactions quotidiennes avec l'environnement - en incluant aussi bien les interactions matérielles que celles idéologiques et politiques - exige souvent un examen de l'économie morale, ainsi que de l'économie politique et l'écologie sociale, en jeu. A.V. Chayanov (1966/1925), E.P. Thompson (1971, 1991), et Jim Scott (1976) nous ont fourni des moyens utiles pour penser l'économie morale. Ils ont présenté l'économie morale comme un moyen de promulguer la compréhension de relations économiques bénéfiques et ordinaires, permettant la subsistance, en se basant sur des luttes sociales. Cette définition peut être particulièrement utile lorsqu'elle est combinée avec des approches liées à l'écologie politique pour enquêter sur «les écologies morales». Ces dernières sont des combinaisons environnementsociété qui sont souvent plus aspirationnelles que actuellement existantes, mais pour lesquelles des efforts considérables sont déployés, et desquelles les dynamiques morales et écologiques sont liées de manière fonctionnelle, comme nous pouvons le constater dans l'intérêt récent porté à l'agroécologie en tant que mécanisme puissant permettant d'assurer les droits alimentaires (De Schutter 2011a, 2011b, 2012). Étant donné l'attention particulière de l'écologie politique envers les relations de pouvoir, les écologies morales, qui

\footnotetext{
${ }^{1}$ Dr. K. Valentine Cadieux, Assistant Professor, Environmental Studies, Hamline University, MS-B1805, 1536 Hewitt Avenue, Saint Paul, MN 55104, USA. Email: kvcadieux01 "at" hamline.edu. I am grateful to Innisfree McKinnon and Colleen Hiner for their enthusiastic convening of this extended conversation exploring regional political ecologies, for including me in the conversation, and for their excellent editorial guidance. I am additionally grateful to the reviewers' helpful demands for clarification, to the many friends and acquaintances who have participated in the relational negotiation of what a region might mean as encountered through the kitchen, and to Laura Taylor for her extended critical engagement with and contributions to this text. This is the third article in Colleen Hiner and Innisfree McKinnon (eds.) 2016. "(Re)considering regional political ecology?", Special Section of the Journal of Political Ecology 23: 115-203.
} 
n'exercent pas de pouvoir considérable, sont souvent négligés par les écologues politiques. Cependant, même si certains phénomènes peuvent ne pas être primordiaux dans le cadre de l'exercice du pouvoir, ils peuvent avoir une influence considérable sur des conceptualisations relationnelles. Cette incompatibilité entre les absences d'intérêt habituelles des écologies morales et leur potentiel contribue aux tensions entre engagements structuralistes et post-structuralistes dans les milieux de recherche actuels se consacrant aux interactions entre sociétés et environnements. Du fait de l'importance de ces deux approches, en particulier pour comprendre ce que Peet et Watts (1993) appellent les écologies de libération (et le discours relatif au régions qui les forment), je soutiens que l'écologie politique fournit un cadre utile pour documenter et analyser les expériences socio-écologiques des régions - non seulement en terme de fonctions de la société et de l'environnement, mais aussi de performance et de conservation des connaissances relatives à ces fonctions.

Keywords: économie morale, systèmes alimentaires, conservation, études critiques régionales, gestion territoriale,recherche participative, justice environnementale, sciences de la gestion intégrée des ressources naturelles.

\section{Resumen}

Hacer la ecologia politicas de las relaciones cotidianas con el ambiente ? relaciones que son a la vez materiales, politicas y ideologicas ? require dar consideración a la economia moral. A.V. Chayanov (1966/1925), E.P. Thompson (1971, 1991), y Jim Scott (1976) entienden la economia moral a traves de discusiones de los 'comunes', derechos de subsistencia, y relaciones economicas basadas en la lucha social. Esta perspectiva ofrece a la ecología política una manera de estudiar ensamblajes socioambientales que residen en las aspiraciones que dirigen practicas cuyas dinámicas morales y ecológicas son vinculados de manera funcional. Caso ejemplar de esto es la agroecologia como mecanismo para asegurar los derechos a la comida (De Schutter 2011a, 2011b, 2012). Dado que la ecología política se enfoca en relaciones de poder, ecologías morales que no ejercen poder considerable tienden a ser menos visibles desde esta perspectiva. El desencuentro producido por la falta de atención a las ecologías morales y su importancia genera tensiones en la literatura academica entre posiciones estructuralistas y posestructuralistas, pero ambos son indispensables para formar ecologías de liberación y los discursos regionales que los sustentan (Peet y Watts 1993). La ecología política ofrece marcos analíticos útiles para documentar y analizar las experiencias socio-ecologicas de regiones, no solo en términos de las funciones de sociedad y ambiente, sino también de su actuación y conservación.

Palabras clave: Economía moral, sistemas alimentarias, conservación, estudios regionales críticos, planificación de uso de suelo, justicia ambiental, gestión integral de recursos naturales.

\section{Introduction}

Writing in the middle of a house turned upside down as I prepare to leave for a season of fieldwork, I find myself ruminating over the Ten fundamental questions of curation as I work through the surprisingly less-unpleasant-than-expected task of emptying out my kitchen to create room for the eating habits of the colleagues who will reside in my house while I am away. Given the amount of effort expended setting up field study on the opposite side of the world, it seems incongruous to be discovering a research insight that has been eluding me in my kitchen detritus. For more than a decade, I have investigated the political ecology of residential land uses in relation to global agri-food regimes, and the ways that people discover and reproduce their sense of place and their understandings of the relationships that constitute their place in the world, a place that is often understood in terms of what geographers call regions. In this work, I have been trying to understand the meaning and function of what people perform via their everyday gestures related to food and land, and the place of these activities in peoples' moral ecologies. It is probable that a kitchen like mine represents a reflection of the political ecologies I investigate, in a more correspondent way than most. As the entry layer of my refrigerator shelfie reveals in Figure 1, my kitchen includes things like pickled mustard greens from Hmong farmers who were involved in a market performance organized by friends and colleagues that invited people to eat with market vendors, jars of wild rice gathered, processed, and gifted to me by Dakota and Anishinabe friends, dried fruits and nuts and grains and beans and beer and fermentation cultures and condiments that each represent a particular form of food production or processing that for 
various reasons I might like to see more widely adopted, and whose stories reside and circulate in my kitchen and among the many who eat here. The insight my kitchen collection suggests has to do with the relationship between the way that people perform their exploration of everyday embeddedness within their relational ecologies and the way researchers might understand analyses of such performances as a form of curation. In this essay, I argue that political ecology researchers are often engaging in a kind of curatorial practice (often of "chains of explanation" for the degradation or sustaining of environments, as enjoined by Blaikie and Brookfield 1987). In an era when so much knowledge exchange, learning, and political organizing takes place via the public sharing of collections of observations, analyses, or sound bites, it seems useful for society-environment researchers to engage with popular modes of understanding and engaging societyenvironment relationships, which are often experienced as having to do with regions, as in the domain of regional planning. The practical strengths of political ecology as an approach are parallel to, and hence likely to be synergistic with, emerging popular curation practices, and tapping into these practices may serve often articulated goals of engaging people in exploring the implications illuminated by studying political ecology. So as I scrape the remaining contents of scores of jars into my compost, I will also document why the kitchen practices reflected here seem useful for reflecting on regional political ecology—and I use them to illustrate the main values I appreciate in this framework.

\section{Function, experience, morality}

Political ecology has something of a double life. As it is often operationalized, political ecology is an analytical tool for investigating the ecological and political functions of society-environment systems and also a normative social and ethical tool, presenting visions of how political ecologies could functionwhether that functional integrity is justified and framed as ecological, sustainable, equitable, or pragmatic. Drawing heavily from critical studies of development, political ecology appears attractive to many reflexive scholars because it provides tools for sympathetic critique of action in the world, and also for considering the enrollment of scholars themselves in the assemblages that act in the political ecologies we study. Political ecology may often seem far removed from the actual world of policy making, in part because of its critical preoccupation with power relations and cultural ecologies—nuances that rarely make it onto the policy stage. But my experience with political ecology and those who use it suggests that its premises and commitments often prompt at least some of us who use it as analytical lens to participate more materially in our regions, for example through participation in planning and governance bodies and processes.

When applied to regions, political ecology frameworks have had three main functions, in my experience. First, regional political ecology frameworks encourage exploration of process and comparison across time and place (an attention to function). Second, they foreground the need for correspondence between narratives and observations of political ecological systems-in other words, they encourage enactive research that makes space within analysis for everyone's experience of the issues being explored (an attention to experience). Enactive research is discussed more below. And, third, they illuminate the systemic relationships and functions that are often gestured toward via aspirational labels such as 'local', 'community', or even 'national'- the normative moral framings often brought to analytic investigations by communities with a stake in researching how regional political ecologies work. I describe this in terms of attention to morality because the scholars I have encountered that are most willing to reflexively engage the moral issues of research have identified themselves as political ecologists. Especially in feminist political ecology approaches, the relational moral issues of both the research topic and methods are likely to be considered an important part of understanding what is happening and what is at stake. This willingness to venture into moral terrain many approaches consider off limits because of its messy, negotiated, and dynamic nature is one of the hallmarks of political ecology, and a significant contribution to its explanatory power and to its attractiveness as an organizing framework for participatory action research. However, the double identity this confers on the political ecology framework has presented a double challenge in my use of the framework, namely the tendency to see political ecology as normative, not analytical, and the tendency of many people conducting social research to not want to focus on their own stance as part of what shapes the systems they study. The relationship between political ecology and regions illustrates both sides of the challenge. After describing the utility of these functions in my experience, I will return to the dilemma of the double identity 
of political ecology and how specific attention to performance, curation, and knowledge cultures may help address this dilemma.

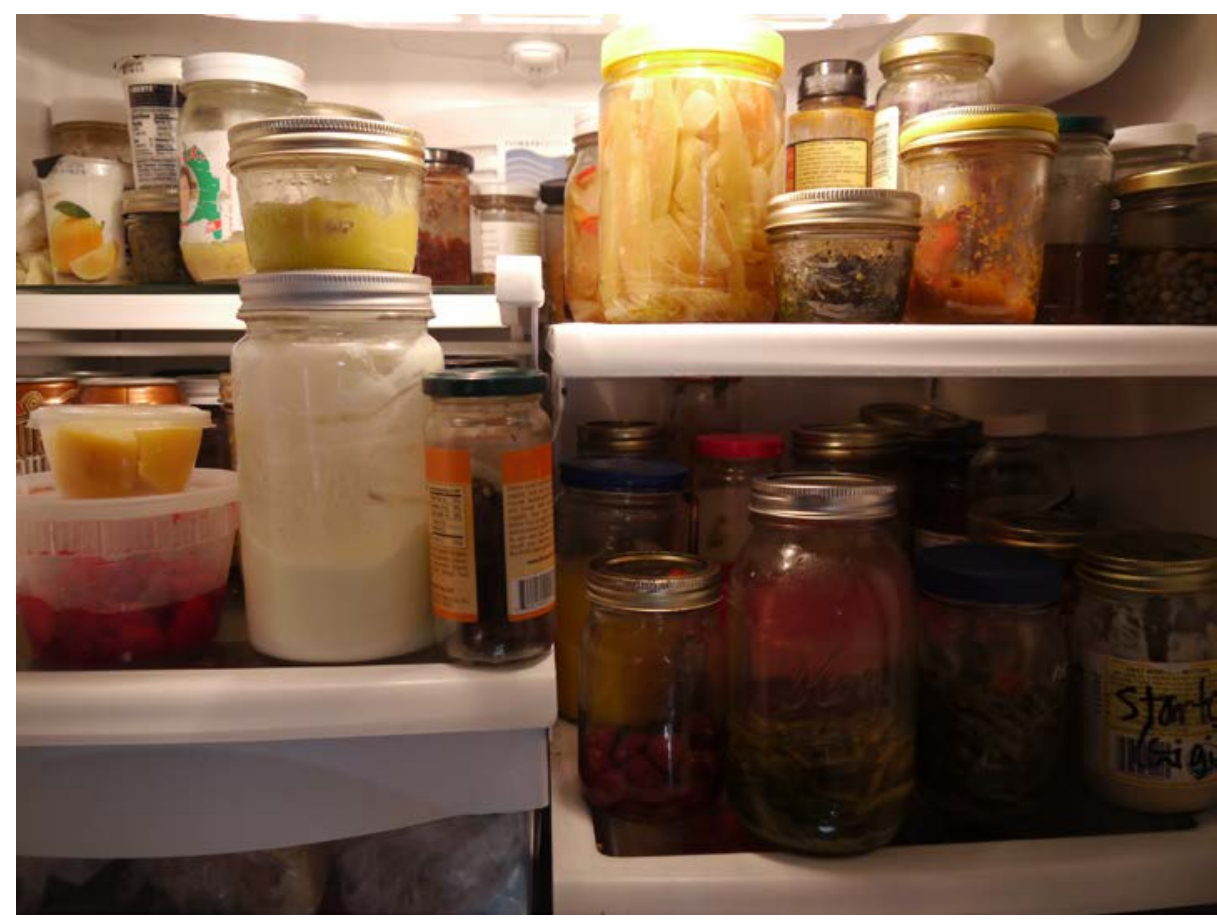

Figure 1: Curated food relationships: moral ecologies are performed through food exchange, preparation, storage, and consumption experiences (although this shelfie glimpse may more accurately show the pre-curation backstage; curation would take place in the more public domain of a meal or documentation).

Firstly, on process and comparison: especially in the investigation of the relationship between social organization and ecological systems, people often ask "how does this work?", and "if this system works like this in the place in question, how is it elsewhere?" and attempt to identify functional similarities in political and ecological conditions in different places. These places and processes are often identified at the regional scale - and the regions are often differentiated by political and physical geographies as well as by ecological functions. The governance of water provide examples of struggles between different functional understandings of regions, since watersheds often exceed and hence problematize the local scales of municipal and state boundaries. The emergent definition of regions appears to be a well-appreciated strength of the political ecology approach. Laura Taylor (2014) captured this sentiment in the panel discussion on (Re)considering regional political ecologies that led to this Special Section in her injunction to "let the region be found through the work you're doing." The simultaneous attention to how society-environment systems work and how they are understood to work is an additional strength that works well at a regional scale. This is partly because the governance of regions usually exceeds both plausible community consensus and the scale of tacit knowledge. This often leads to situations with an explicit need to negotiate the politics of environmental knowledge, using the technologies of representation that are common fodder for political ecology analysis, such as maps of flows, hazards, vulnerabilities, and representations of networks - it also makes it hard to ignore the dynamics of competing interests or understandings, a crucial condition contributing to openness to exploration and negotiation. In such contexts, the definition of regions often relies 
on categories that play to the strengths of the political ecology framework, as we see in attempts to delimit bioregions, cultural regions, watersheds, or even foodsheds.

Secondly, regional political ecology frameworks are helpful for exploring the relationship I just alluded to-between the functions of political ecological processes and diverse understandings and experiences of these functions and processes. Attention to experience is arguably part of the normative ethos of political ecology. The approach has been cross fertilized by insights from feminist action research, agrarian and peasant studies, actor network theory, and concerns about qualification and justification from the 'regulation school.' Practitioners of political ecology often espouse a commitment to analyses that include attention to complex and contested normative experiences within case studies and also, in exemplary cases, commitment to respecting analyses emerging from within the case (Flyvbjerg 1998; Hetherington 2011; Massey 1993; Thevenot and Boltanski 2006). This more distributed agency in the analysis of political ecology plays a significant role in the growing attractiveness of the approach to graduate students and community engaged scholars. Working within case studies, scholars are much better able to build analytic relationships if they are able to respect and work with 'informants', rather than extracting popular understanding as data that is only legitimated by scholarly attention to it. A significant dynamic within the best of regional political ecology has been the practice of actively situating research within ongoing explorations in the region. Laura Taylor's work on land use planning in the Greater Golden Horseshoe (GGH) region of Ontario provides an excellent example of the most publicly-engaged version of this form of feminist political ecology work. Taylor engages plans for regions, parks, and protected landscapes such as the GGH Greenbelt, enrolling various communities of practice in systematic scholarship about ongoing land use planning challenges, in a context where the concept of "region" has been institutionalized as both territorial and relational through "regional municipalities" and "regional growth plans", with a specific meaning of region emerging out of the relationship of urban agglomerations and affected adjacent spatial territories (Taylor 2007; Amati and Taylor 2010). Recognizing that regions are a central focus of land use planning, Taylor focuses on regional land use planning challenges along with students in academic case study courses, with practitioners engaged in planning and evaluation, as well as with policy makers and the citizen, advisory, and scientific panels she engages in this work. She has, for example, included her students in policy meetings, mentoring them to provide scholarly reports for policy makers-and producing policy reports for scholars (see, for example Cadieux, Taylor, and Bunce 2013; Taylor 2007; Taylor et al. 2010). The knowledge feedback circuits set up in this kind of relational research are a significant part of what makes this situated research so effective: in addition to relationships of trust that help boost the salience and credibility of the research process itself, being able to use the research process to track the results of events, interventions, and systemic functions under observation vastly improves the legitimacy of such research processes-a possibility that is amplified when the research is yoked to adaptive management processes (Cash et al. 2003).

This emphasis on aa correspondence between lived experiences and scholarly analysis of political ecological systems increases the fidelity and recognition of consequent explanations of nature-society relationships (cf. Sayre 2010). It also helps incorporate explorations of power and morality, a key contribution of regional political ecology frameworks, and also one of their most contentious. Although it may be clear that the experience of morality and power plays a role in most topics political ecology addresses, investigating the roles that experiences of morality and power play appears from scholarship to be best left to humanists, behavioral economists, or clerics. How many analyses trail off at the very crux of their most interesting questions with a helpless gesture toward things that cannot be answered with the methods at our disposal? ${ }^{2}$ This often happens even when the exercise of power-or the mustering of justifications for a

\footnotetext{
${ }^{2}$ Two sources I have drawn heavily on in my work on land use motivations provide classic examples of such abrogation: In Healy (1984: 18): "The urbanite's love affair with the American forest is a subject with complex psychological roots, many classic manifestations in literature and art, and quite varied political results. I mention it here to acknowledge its importance, and to admit that its analysis is quite beyond my disciplinary competence." In Punter (1974: 436): "Any attempt to grapple with questions of motivation demands a complex psychologically-based research procedure that is well beyond the scope of this thesis and the author's expertise. This is not to argue that such questions are not fundamental to the ultimate goal of understanding man in the landscape." In a common if uncharacteristic way, political ecology also tends to ignore experiential motivations in favor of structural analyses, despite the availability of excellent
} 
normative moral position-is clearly central to understanding what is at stake, and how it is unfolding. The practice of regional political ecology, especially when attending to the dynamics outlined above, can substantially improve analytical purchase on the functions of both power relations and moral stances within political ecologies_ and the study of these political ecologies.

\section{Experience and analysis: ecology, morality, and curation}

Let me return briefly to what I have described as the 'double life' of political ecology, and the problems I have encountered with this double life. When I assert to my colleagues the utility of political ecology as an approach to understanding the society-environment dynamics of regions, these colleagues, especially those in the environmental science and management fields, do not see political ecology as residing in the pantheon of approaches that are actually used for integrating systemic understandings of society and environment. Rather, they argue that political ecology resides primarily within the critical social sciencesperhaps a useful analytical tool in an academic sense, but one they see circulating in actual managerial use so little that they do not prioritize it as something they should understand and engage. Political ecologists may recognize this as what Robbins refers to as the tension between the "hatchet" and the "seed" (2011: 99): we may be in the habit of critiquing more than we radically rebuild.

My experience with this perspective in academic contexts dedicated to public engagement at the scale of regional environmental management suggests an interesting flip side to the same three reasons above where I have suggested regional political ecology frameworks might be useful. Scholars who have invested effort in the layer-cake model of landscape ecological planning and in integrative and somewhat critical frameworks such as agroecology, adaptive co-management, or integrated water resource management, for example, see themselves already thinking about comparison and systemic relationships and functions. They are also usually willing to spend time considering how involved constituencies understand and engage with the systems in question, and to engage in some participatory methods-meaning that pleas for more reflexive scholarship may appear to them to be aimed at others, or aimed toward a less enlightened historical period of environmental scholarship. However, the same epistemological chasms still divide most interdisciplinary projects with which I have worked: scholars studying ecological dimensions and social dimensions tend to underestimate the importance of the integration of these dynamics, and to consider the 'other' way of looking at the problems at hand as less central. I hear this often around questions of food security, for example, where scholarship on just food distribution systems and power relations are often distanced from 'harder' science investigations, in agronomy and the perennially popular question of how to feed the world (likewise, social sciences and humanities keep their distance from natural sciences as well).

Especially when social patterns of organizing academic inquiry reinforce such distancing (social and agronomic studies of food security are conducted on completely separate campuses at Minnesota's land grant university, for example), part of what seems valuable about exploring regional political ecologies is that such exploration helps to undermine the popularity of superficial characterizations, such as 'the state', 'agribusiness', or 'consumers.' Instead, such explorations can press investigators to think about what functions and processes are useful to understand, about how those interconnect (for better or worse, mutually sustaining, reinforcing, or interfering), and about how such understandings enable engagement with the systems under study. In this way political ecology allows understanding of which dynamics of natural and social systems can be negotiated with-and how. Part of what is involved in this more relational understanding of ecologies is an analytical understanding of the functions of moral stances themselves in contributing not only to the way that people experience and navigate ecologies, but crucially to the very way ecologies are shaped, reproduced, and maintained. In contrast to many well-intentioned ecological sciences,

work on moral geography, geographies of care, and feminist political ecology (e.g. Conradson 2003; Lee and Smith 2011; Rocheleau et al. 1996; Smith 2000) that could help integrate structuralist and poststructuralist approaches. Especially in the 'first world' context studied by much urban political ecology, we can see analyses of the experience of morality and power play out in very different ways when discussing the power relations structuring general environmental experiences or, in contrast, when discussing embodied experiences of race or colonial power (contrast Heynen 2014 with Heynen 2015, for example). Attention to more reflexively handling such contrasts may help place our own research practices within the frame of analysis in the ways discussed here. 
where moral stances tend to be treated as implicit backgrounds to impressive arrays of scientific evidence that should influence decisions without having to seem moral, in this more reflexive view, moral ecologies provide a way to understand the inherent difference and shifting power assemblages involved in the very constitution of ecological systems. This approach combines lessons from structuralist concerns with political economy and post-structuralist concerns with radical difference, to help organize meaning in investigations of systems considered unmanageably messy and complex. So the study of something like 'local' food, along these lines, may not be approached only in terms of the impact and infrastructure of mileage or the maintenance of particular microbial communities, but by accounting of what is deemed meaningful in agrifood supply chains, and the relational qualities of markets and soil interactions-measures likely to require a much more collaborative and negotiated approach to understanding whose locality matters where, and how (McGirr and Batterbury 2016).

In the decades that "regional political ecology" has been in use as a construct (since Blaikie and Brookfield, 1987), there has been a marked emergence of the vocabulary and practices of curation as a way to organize artifacts. This has been particularly notable in my area of study — food-related land uses_and even more pronounced in fields related to digital scholarship: searching for "curation" and "social science" elicits hundreds of "data curation" jobs, most of them for junior scholars and students, who are sought to help collect and organize, selectively display, and analytically interpret the surfeit of artifacts that are constantly being produced. Beyond digital scholarship, the rise of internet access-and social media-has provided the need for sense-making activities to sort through the overwhelming amount of available content, and also broader access to tools for curating such content. Tools such as Facebook, Instagram, Tumblr, Twitter, or

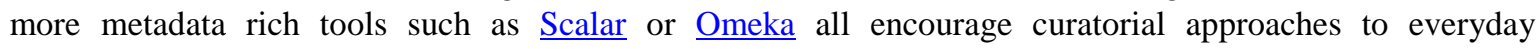
experience that emphasize the selective presentation and interpretation of collections of information-a popularization of approaches that may once have been practiced in the privileged domains of scholarship or collectorship.

Such curation has become a force to be reckoned with in discourse analysis, as themes such as those in analyzing society-environment relationships often come pre-curated by the people participating in them (several of my colleagues have started analyzing the hashtags and Twitter themes coming out of environmental management meetings, for example). Especially in residential spaces such as the yard and the kitchen, the careful collection, sorting, and presentation of the products and processes of political agroecological relationships (such as those on display in gardens) provides a vernacular analogue to many of the traditional cataloguing and discourse analysis methods of regional political ecology (such as litanies of reasons for soil degradation, building on Blaikie and Brookfield's 'chains of explanations' framework). I want to bring these more popular versions of curation into the regional political ecology conversation, for a few reasons.

Most obviously — and my colleagues who also conduct interviews about land use and food practices will be familiar with these reasons - there is a remarkable amount of creative energy being put into investigation of society-environment relationships through the elaborate curation of everyday practices by activists, bloggers, and foodies. Sometimes such investigation demonstrates willingness to think publicly about the relationships between everyday practices and potentially very uncomfortable social and ecological dynamics - the status quo social problems of neocolonial settler societies, for example. This exploratory willingness very much reflects the popular input often called for (and praised) in exhortations claiming that public participation is necessary in environmental management. The meaning-making enabled by popular curation practice may also help mitigate some aspect of the disengagement, apathy, and hegemony that inhibit powerful participation (Miessen 2010). This engaged analytic praxis may perhaps be much more widespread than we imagine, if we look for it outside disciplinarily familiar domains. It reinforces what I described above as the tenuous strengths of political ecology: respecting diverse analytical voices, and enabling researchers to take experience seriously, and to analyze their own experience within enactive research. Pedagogically, it seems these popular impulses toward curation could benefit from interaction with the critical perspectives of political ecology. For example, imagine a Pinterest board or Facebook group where participants were encouraged to catalogue and explain observed impulses toward bioregionalism, probing beyond the seeming sentimentality of much localism, or going beyond superficial criticism of 
localism. Such a scenario has a lot of promise for the holy grail - liberation ecology public scholarship, and action research, It means figuring out how to yoke the compelling and rewarding qualities of curating a yard or kitchen to the kinds of questions asked in critical development studies or agrarian political economy. These are questions of how to repair the damage done by colonialism and to disrupt its reproduction in the society-environment relationships being explored and curated by a community of learners.

\section{Curation and the everyday function of regions}

I drew heavily on work promoting "regional political ecology" in the era after the heyday of regional studies, yet prior to the 'scale debates' about the way certain interpretations of the idea of regions and the hierarchies of scale tend to be privileged (e.g. Walker 2003; see Cadieux 2011; Cadieux and Hurley 2011; Qviström and Cadieux 2012). But I will admit that I had not paid very close attention to the practical or conceptual work done by the concept of 'regions. ${ }^{3}$ What regions do only became salient as I set myself the task of trying to unpack how the people I study really do relate their somewhat precious yard and kitchen curations with their functional understandings of society and space. Are their efforts at cataloging and cultivating collections of food plants_or recipes or food production technologies-trying to decolonize resource relationships? Many people make substantial assertions about the social justice impacts of their gardening, for example (Slocum and Cadieux 2015; Cadieux and Slocum 2015). But such claims are often muddied in practice where activities like well-intentioned gardening are conflated with practices that contribute to gentrification, and the competitive building up of city-regions as places made better for investment.

In enactive research, researchers participate in the social dynamics they are exploring, and they find domains to investigate their analyses in practice. Given my own interest I spend a considerable amount of my time grappling with the gentrifying idealizations of the new regionalism in my research on land use tensions around urbanization and food production. Many of the policy-makers, funders, and city builders who hold power over what can be done with urban land think of regions in abstracted and boosterish ways, as the city regions playing their part in macroeconomic models. This version of 'the region' seems very difficult to identify in practice. I am interested in trying to understand how regions might function as modeled (for example, finding some underlying empirical justification for the tenet of "highest and best [land] use"). But I generally find it more rewarding to put much of my effort in public research projects trying to elicit attention to the finer grained experience of everyday life: where it is most possible to assess what people are doing, and how is that working? Or how can we better understand the political, economic, moral, and ecological dynamics that relate us to other people across space? Especially when we're talking about why local schools cannot afford local cabbages in Minnesota, it's not so much the climate and the social and spatial organization of our region that matters so much (even if they are important) as it is the labor and water and food distribution regimes that organize agricultural production in the other places supplying our cabbage.

This is not to say that the functions of the region don't pop up in between these scalar bookends of everyday space and the spaces of global agri-food regimes: Minnesota-consumed cabbage, for example, often comes from irrigated California farms (which have consistently been able to sell organic cabbage at half the wholesale rate farmers in Minnesota can afford to offer), and comparisons of regional water regimes have

\footnotetext{
${ }^{3}$ For helpful investigations of some of this intellectual history, see Neumann (2009, 2010) on scale and region in political ecology. Mahon and Keil (2009) address scale theory in political economy (see also Sayre 2005). More recently, the Biological economies project in Aotearoa New Zealand has been grappling with the critical integration of relational and territorial understandings via their method of "enactive research" (Lewis et al. 2013). Summarizing their approach to enactive research and distinguishing it from other methodologies, they argue four main points (p.189): (1) "Participative knowledge production is a starting point for more performative engagement, and [(2)] representational knowledge ... that has the appearance of comprehensiveness is always compromised by its boundaries, sampling frames and ensuing partialities." They continue (3): "Where our practice of enactive research diverges from participatory action and firstgeneration alternative economy approaches ... is that we see enactive research as an opportunity to take [our work] to audiences in multiple settings, including policy and investment forums"; (4) (p.181) "...enactive research encounters such as ours offer a platform for narrating new economic worlds and institutional capabilities such that new value can be made, and made to stick, in territory and thus become available for others." This work helpfully illustrates the spatial extent commonly used when people refer to regions, in contrast to the somewhat straw-dog argument that 'region' mostly denotes abstract categories such as 'First World' or 'Global South' as a region.
} 
become a fairly common focal point for arguments about relocalization of food systems. Regional labor systems might soon become more common (see Food Chain Workers Alliance 2012; Henderson and Spula 2011). Also common in these arguments are representations of regions and their communities in terms that we might recognize from Ben Anderson's descriptions of the construction of nationalism (Anderson 1991) and that have been critiqued in work on alternative food systems as "defensive localism" (DuPuis and Goodman 2005; Winter 2003). This version of regions familiar from local foods discourse (as well as from NIMBY land use politics) has obvious downsides. Localism tends to conflict with macroeconomic theories of comparative advantage (and arbitrage), alienating dominant bureaucracies without necessarily providing substantive (or moral) explanations about why social relations at the scale of the region are preferable. Perhaps most frustrating from the normative position familiar in political ecology work is the way that sentimental appraisals of regions tend to make it harder to discuss how regional social relations might otherwise be organized to avoid some of the difficulties and problematic power relations often negatively attributed to larger scales in endeavors such as food production.

Considering everyday curation as a humanistic analogue to 'citizen' (or public) science may help us appreciate the upside of regions as heuristic devices useful for the reasons I have outlined. A culture of populist curation encourages people to explore and come to critical and actionable conclusions about the infrastructure of their everyday lives. Without considerable social infrastructure to translate the impulses and fragmentary understandings we often see, for example in foodie-ism, foodies do not usually make substantive change via pickles and locally made specialty items and the arrangement of their yards-but they may make heuristics that remind them what to prioritize and what they understand and which relationships to cultivate that are useful in specific regions. Since regions are often defined by the scale of ecological and political relationships engageable in a place, one of the most important aspects of the kind of popular curation I'm describing, from the perspective of regional political ecology, is that it appears to contribute to learning how to organize with others: how to argue for which values are important enough to support and defend. ${ }^{4}$ And the everyday way that people experience things and relate them to the changes in the systemic relationships around them, such as in the case of local "regional" food, seems to provide a crucial feedback potential for adaptive social learning and management systems.

\section{Everyday political ecology, the moral agency to change, and a progressive sense of region}

In the field of art curating, where the term is most familiar and also most professionalized, there is considerable consternation over the popularization of curation and the hollowing out of the curatorial. The field of socially engaged environmental art has come to closely parallel much work in political ecology. For examples of approaches to ecology that take the politics of meaning and experience seriously, see the work of Natalie Jeremijenko, Marina Zurkow, Buster Simpson, or Christine Baeumler, all of whom craft artistic processes around everyday ecologies - that also take seriously popular ecological experiences, and the ways these might be intensified and more meaningfully interpreted by engaging ecologies via art. Attention to "social practice" in this artistic work has made me think about the function of practicing habits related to food and land in light of an emphasis on social organizing and popular meaning-making. Such habits can potentially be yoked to the everyday practices of experiencing, analyzing, and potentially changing regional political ecologies. Innumerable cultural technologies bring us our meals and reproduce our political ecologies - and a central theme of the many socially engaged disciplines concerned with these dynamics is that we need to learn to respect the range of cultural technologies, and also to engage their moral ecologies (from canning to hydrogenation), with their different pressures and practical systemic dynamics. Curator Maria Lind recently responded to a request by Jens Hoffmann to define the curatorial in their Art Basel discussion of his 2013 edited collection Ten fundamental questions of curation, the collection that made me see my kitchen in more distinctly curatorial terms. Her response captures for me the value of a popular yet

\footnotetext{
${ }^{4}$ This is one of the core reasons I have argued that we should not dismiss what many critics argue is merely symbolic redemption of high impact lifestyles, even if that is a hugely motivating component of the impulse, see Cadieux 2005, 2008 and Slocum et al. 2011.
} 
also rigorous engagement with regional political ecology understood from a curatorial perspective-a sense of the way that analytical agency involves empowerment to speak from one's own experience, and also to be an agent of the ongoing reproduction and change of a region and its politics and ecology, beyond the merely solipsistic performance of personally satisfying curation:

[By curatorial] I mean a practice that goes beyond curating, which I see as the technical modality of making art go public in various ways. "Curating" is "business as usual" in terms of putting together an exhibition, organizing a commission, programming a screening series, et cetera. "The curatorial" goes further, implying a methodology that takes art as its starting point but then situates it in relation to specific contexts, times, and questions in order to challenge the status quo. And it does so from various positions, such as that of a curator, an editor, an educator, a communications person, and so on. This means that the curatorial can be employed, or performed, by people in a number of different capacities within the ecosystem of art. For me there is a qualitative difference between curating and the curatorial. The latter, like Chantal Mouffe's notion of the political in relation to politics, carries a potential for change.

I will end with an example that made me think through regional political ecology frameworks as curatorial. As I get ready for a field study trip in Aotearoa New Zealand by cleaning my kitchen, I am finishing up eventually perishable goods like Milo, a Commonwealth Nestlé malted barley chocolate milk beverage. I wonder while drinking it whether the version of it I remember (to which I was introduced doing graduate fieldwork in Christchurch) will be as good as what we doctor up at home, halving tins of the Singaporean version of the drink (all that's available in Minnesota) with cocoa powder that is fair trade and organic and with malted milk that I had to mail order when I couldn't find it at either the local co-ops or large grocers. The down-homey malted powder comes from a 'Real Food' distributor aggregating specialty groceries and that I suspect is a subsidiary of a large retailer. The cocoa and Singaporean ingredients obviously travel along distanciated global networks, made as non-engageable as possible despite the many claims by the manufacturers about labor relations and nutrition respectively. And while I recognize that regional relations are not inherently less racist or more equitable, it is nevertheless regional networks that make it possible for me to engage with the complex relational networks of this food's production. Minnesota's networks of food coops, for example, function very regionally - even if the regional scale is diverse, with the Twin Cities being a sub-region of the larger prairie-populist region of historical co-ops (Ergstrom 1994), and with individual co-ops functioning significantly in subsections of the metropolitan region.

I am inclined to characterize the goal of the kind of 'enactive research' that I have described above as making it possible for people to carry out action research that has an effect on the systems studied and that helps people become aware of, understand, and perhaps revise their justifications for the kinds of actions they're motivated to take. In relation to the social organizations that contribute to feeding people, such research often focuses on regional networks that people would like to critically understand and improve. These networks are often regionally organized, with strong production chain clusters located in functional proximity, and where actions take place within territorial boundaries. The centers and boundaries shift as relationships across space change. These are all characteristics that could be claimed for the specific provisioning relationships that have allowed me to consistently supply myself with Singaporean Milo. The grocery institution that is the Twin Cities' United Noodle store where I buy it has been maintained by diverse communities of eaters. The supply chain possibilities that make possible my indulging in Milo as a guilty memento of sociable fieldwork moments (along with its more virtuous replacements) are carefully built and slowly discovered regional relationships that easily become taken for granted—but whose regional specificity and value are painfully rediscovered each time one relocates from a familiar region and loses access to meaningful foods, along with everything they may represent about understanding one's place in the world, and one's reliance on the landscapes and social relations of, for example, food production.

Before I learned to want foods with qualities that are difficult to understand without political ecology terminology (or to understand Milo enough to hack it!), I knew very little about the many ways that foods are 
processed-about the role of barley in malt balls, for example, or the role of malted milk in keeping brewery technologies alive through the Prohibition period in the US (technologies that are now subsidizing and forging economic geographies of emerging 'food hubs'), or, frankly, about the extraordinarily perilous labor involved in the cultivation, harvest, and processing of cocoa. Just as much as with the much more commonly 'curated' foodstuffs I'm clearing out of my kitchen - the fancy and particular and relationship-embodying things pictured above and the jams and artisanal things people like to use to characterize 'regional food'these more processed foods like Milo play an important role in the heuristic that kitchen foods are providing for regional political ecology. Processed foods into which we may gain some insights represent and perform important things that we can figure out about the knowledge cultures that are necessary to engage, for example, if I want to effect change in the agroecological systems I work within. As I try to understand why I am attached to all my jars of preserved food knowledge, I am coming to recognize that an active curatorial stance toward the regional political agroecologies represented here enables me to take my experience into the social milieu where a more collective sense of what the region is, and how it functions and is negotiated (cf. Cook et al. 2000 and Cook et al.'s http://www.followthethings.com project). My curatorial approach to my kitchen is both dependent on my social experience and it allows me to share material artifacts of this social experience; much like landscape investigation, this approach provides a framework particularly supportive for enactive research.

In the best case scenario, I see the negotiation of regions enabled by this approach as crucial to institutionalizing the qualities Doreen Massey identified as contributing to a progressive sense of place: not static, not simply enclosed, without single identities, and with multiple sources of uniqueness (Massey 1993). Toward a progressive sense of region, we can argue that the everyday and scholarly analysis and curation involved in the practice of regional political ecology can empower people to embrace the moral as a creative shaping modality, a series of practices that are not only curated as a performative display, but that are actively used to build healthy, just socio-spatial relationships. And the region provides an experientially parsimonious place to explore, negotiate, curate, perform, and in other ways institutionalize such moral ecologies in place.

\section{References}

Amati, M. and Taylor, L. 2010. From green belts to green infrastructure. Planning Practice and Research 25(2): 143-155.

Anderson, B.R. 1991. Imagined communities: reflections on the origin and spread of nationalism. London: Verso.

Blaikie, P.M. and H.C. Brookfield. 1987. Land degradation and society. London: Methuen.

Cadieux, K.V. 2005. Engagement with the land: redemption of the rural residence fantasy? In Essex, S., Gilg, A., and R. Yarwood. (eds.). Rural change and sustainability: agriculture, the environment and communities. Cambridge: CABI. Pp.215-229.

Cadieux, K.V. 2008. Political ecology of exurban 'lifestyle' landscape at Christchurch's contested urban fence. Urban Forestry and Urban Greening 7(3): 183-194.

Cadieux, K.V. 2011. Competing discourses of nature in exurbia. GeoJournal 76(4): 341-363.

Cadieux, K.V. and P. Hurley. 2011. Amenity migration, exurbia, and emerging rural landscapes: global natural amenity as place and as process. GeoJournal 76(4): 297-302.

Cadieux, K.V. and R. Slocum. 2015. What does it mean to do food justice? Journal of Political Ecology 22:1-26.

Cadieux, K.V., L. Taylor., and M. Bunce. 2013. Negotiating 'protected countryside' in the Greater Golden Horseshoe Greenbelt Plan: material landscapes and abstract ideals in the city's countryside. Journal of Rural Studies 32: 307-319.

Cash, D.W., W.C. Clark, F. Alcock, N.M. Dickson, N. Eckley, D.H. Guston, J. Jager and R.B. Mitchell. 2003. Knowledge systems for sustainable development. Proceedings of the National Academy of Sciences 100(14): 8086-8091. 
Chayanov, A.V. 1966/1925. The theory of peasant economy. Edited by D. Thorne, B. Kerblay and R.E.E Smith. Madison: University of Wisconsin Press.

Conradson, D. 2003. Geographies of care: spaces, practices, experiences. Social and Cultural Geography 4(4): 451-454.

Cook, I., P. Crang, and M. Thorpe. 2000. Regions to be cheerful: culinary authenticity and its geographies. In Naylor, S. Ryan, J. Cook, I., and D. Crouch. (eds.) Cultural turns/geographical turns: perspectives on cultural geography. Harlow: Routledge.

De Schutter, O. 2011a. Agroecology and the right to food. Report presented at the 16th Session of the United Nations Human Rights Council.

De Schutter, O. 2011b. The right of everyone to enjoy the benefits of scientific progress and the right to food: from conflict to complementarity. Human Rights Quarterly 33(2): 304-350.

De Schutter, O. 2012. The right to food: a weapon against global hunger. Friedman Seminar Series. Medford, MA: Tufts University.

Dupuis, E.M., and D. Goodman. 2005. Should we go "home" to eat? Toward a reflexive politics of localism. Journal of Rural Studies 21(3):359-371.

Ergstrom, L. 1994. Make no small plans: a cooperative revival for rural America. Rochester, Minnesota: Lone Oak Press, Ltd.

Flyvbjerg, B. 1998. Rationality and power: democracy in practice. Chicago: University of Chicago Press.

Food Chain Workers Alliance. 2012. The hands that feed us: challenges and opportunities for workers along the food chain. http://foodchainworkers.org/wp-content/uploads/2012/06/Hands-That-Feed-UsReport.pdf

Healy, R.G. 1984. Forests in an urban civilization: land use, land markets, ownership and recent trends. In G. A. Bradley (ed.) Land use and forest resources in a changing environment: the urban/forest interface. Seattle: Washington University Press. Pp.17-34.

Henderson, E. and J. B. Spula 2011. Building the movement: labor in the Northeast food system. Northeast Sustainable Agriculture Working Group. http://nesawg.org/sites/default/files/WorkersintheNEFoodSystemOct2011_1.pdf

Hetherington, K. 2011. Guerrilla auditors: the politics of transparency in neoliberal Paraguay. Durham: Duke University Press.

Heynen, N. 2014. Urban political ecology I: the urban century. Progress in Human Geography, 38(4): 598604.

Heynen, N. 2015. Urban political ecology II: the abolitionist century. Progress in Human Geography In press.

Hoffmann, J. (ed.) 2013. Ten fundamental questions of curation. Milan: Mousse Publishing.

Lee, R. and D.M. Smith. 2011. Geographies and moralities: international perspectives on development, justice and place. London: Wiley.

Lewis, N., R. Le Heron, H. Campbell, M, Henry, E. Le Heron, E. Pawson, H. Perkins, M. Roche and C. Rosin. 2013. Assembling biological economies: region-shaping initiatives in making and retaining value. New Zealand Geographer 69(3): 180-196.

Mahon, R. and R. Keil. 2009. Introduction. In R. Keil and Mahon, R. Leviathan undone? Towards a political economy of scale. Vancouver: UBC Press. Pp. 3-23.

Massey, D. 1993. Power-geometry and a progressive sense of place: local cultures, global change. In J. Bird et al. (eds.) Mapping the future. New York: Routledge. Pp.59-69.

McGirr, H.K. and S.P.J. Batterbury. 2016. Food in the city: urban food geographies and 'local' food sourcing in Melbourne and San Diego County. Geographical Research 54(1): 3-18. esearchGate

Miessen, M. 2010. Democracy revisited (in conversation with Chantal Mouffe) In Miessen, M. (ed.) The nightmare of participation (Crossbench praxis as a mode of criticality). New York/Berlin: Sternberg Press. Pp. 105-160. 
Neumann, R.P. 2009. Political ecology: theorizing scale. Progress in Human Geography, 33, 398-406.

Neumann, R.P. 2010. Political ecology II: theorizing region. Progress in Human Geography, 34, 368-374.

Peet, R. and M.J. Watts. 1993. Introduction: development theory and environment in an age of market triumphalism. Economic Geography 68: 227-253.

Punter, J.V. 1974. Urbanites in the countryside: case studies of the impact of exurban development on the landscape in the Toronto-centred region 1954-1971. Ph.D. dissertation, University of Toronto.

Qviström, M. and K.V. Cadieux (eds.) 2012. Special Issue section on The peri-urban interface: between planning history and landscape history. Landscape Research 37(4).

Robbins, P. 2011. Political ecology: a critical introduction. Malden, MA: Blackwell.

Rocheleau, D.E., B.P. Thomas-Slayter and E. Wangari (eds.). 1996. Feminist political ecology: global issues and local experiences. New York: Routledge.

Sayre, N.F. 2005. Ecological and geographical scale: parallels and potential for integration. Progress in Human Geography 29 (3): 276-290.

Sayre, N.F. 2010. Cross-site comparison in Long Term Social-Ecological Research: identifying scales and processes through maps and local knowledge. Annual meeting of the American Association of Geographers, Washington, D.C.

Scott, J.C. 1976. The Moral economy of the peasant: rebellion and subsistence in Southeast Asia. New Haven: Yale University Press.

Slocum, R. and K.V. Cadieux. 2015. Notes on the practice of food justice in the U.S.: understanding and confronting trauma and inequity. Journal of Political Ecology 22: 27-52.

Slocum, R., J. Shannon, K.V. Cadieux and M. Beckman. 2011. 'Properly, with love, from scratch': Jamie Oliver's food revolution. Radical History Review 110: 178-191.

Smith D.E. 2000. Moral geographies. ethics in a world of difference. Edinburgh: Edinburgh University Press.

Taylor, L.E. 2007. The production of nature in planning for urban expansion: a cultural landscape study of new urban growth in Oakville, Ontario. PhD dissertation, University of Toronto.

Taylor, L. 2014. (Re)considering regional political ecologies: theory, utility, and applications. Annual meeting of the American Association of Geographers, Tampa.

Taylor, L. et al. 2010. Grad students in environmental studies at York find thinking regionally still makes sense, and ENVS 6124 Urban-regional Planning Students with L. Taylor. Ontario Planning Journal 25(3): 5 and 6-7.

Thevenot, L. and L. Boltanski. 2006. On justification: economies of worth. Princeton: Princeton University Press.

Thompson, E.P. 1971. The moral economy of the English crowd in the eighteenth century. Past and Present 50: 76-136.

Thompson, E.P. 1991. The moral economy reviewed. In E.P. Thompson Customs in common. New York: New Press, London: Merlin Press.

Walker, P. 2003. Reconsidering 'regional' political ecologies: toward a political ecology of the rural American West. Progress in Human Geography 21(1): 7-24.

Winter, M. 2003. Embeddedness, the new food economy and defensive localism. Journal of Rural Studies 19(1): 23-32. 